\title{
Public Perceptions on City Landscaping during the Outbreak of Coronavirus Disease: The Case of Vilnius Pop-Up Beach, Lithuania
}

\author{
Rasa Pranskuniene * (D) and Dalia Perkumiene
}

itation: Pranskuniene, $\mathrm{R}$

Perkumiene, D. Public Perceptions on

City Landscaping during the

Outbreak of Coronavirus Disease:

The Case of Vilnius Pop-Up Beach,

Lithuania. Land 2021, 10, 32. https://

doi.org/10.3390/land10010032

Received: 11 November 2020

Accepted: 29 December 2020

Published: 2 January 2021

Publisher's Note: MDPI stays neutral with regard to jurisdictional clai$\mathrm{ms}$ in published maps and institutional affiliations.

Copyright: (C) 2021 by the authors. Licensee MDPI, Basel, Switzerland. This article is an open access article distributed under the terms and conditions of the Creative Commons Attribution (CC BY) license (https:// creativecommons.org/licenses/by/ $4.0 /)$.

Faculty of Bioeconomy Development, Vytautas Magnus University Agriculture Academy, Universiteto Str. 10, Akademija, LT-53361 Kaunas, Lithuania; dalia.perkumiene@vdu.lt

* Correspondence: rasa.pranskuniene@vdu.lt; Tel.: +370-615-18332

\begin{abstract}
The article sought to understand public perceptions on city landscaping during the outbreak of COVID-19. The research aimed to discuss the theoretical aspects related to restrictions on travel during the pandemic and city landscaping and to conduct an empirical study of experiences of the Vilnius Pop-up Beach, Lithuania. The thematic analysis selected for the empirical study is not limited and flexible, allowing for revealing the experiences and public opinion, including that expressed in the media, relating to the Vilnius Pop-up Beach. The analysis resulted in the identification of several themes: "Nostalgia for heroic landscape", "Changing memory landscape", and "Enjoying the landscape of freedom", which demonstrated the controversy surrounding the changing city landscape. Analysis showed the interaction of public perceptions on city landscaping. The results of this research highlight the importance in future sustainable landscape development of paying attention to the different city experiences. Public perceptions should be heard and respected when considering the unique landscape of the past, present, and future and its impact on city memories. Thus, possible directions for future research should include more in-depth explorations on alternative travel experiences, looking for possible uncovered, unforeseen, sensitive, and meaningful travel experiences, which emerged during the outbreak of COVID-19.
\end{abstract}

Keywords: city landscaping; freedom to travel; right to the city; public perceptions

\section{Introduction}

The outbreak of COVID-19 in most countries has led to increasing efforts to restrict the free movement of individuals. Health concerns have always steered urban planning and the design of cities, as noted by Moritz, citing Wintle [1]. Hooper [2] noted that in late medieval times, wealthy residents of European cities often retreated from cities during plagues. Newman Leigh [3] argued that pandemics have marked the urban landscape. Pandemics and new diseases, as Hall et al. [4] pointed out, have long had a transformational effect on environments and societies. Restrictions on travel have slowed, but not stopped, the free movement of persons, while also not reducing the need and desire of individuals to travel or seek alternatives to travel. According to Jasiński [5], the outbreak of COVID-19 affected not only almost all spheres of human life, but also the possibilities and way of using urban public space.

Amongst the burgeoning discussions and research related to tourism and COVID-19, as Sigala [6] and Strielkowski [7] noted, the public is calling for the pandemic to be universally seen and used as a transformative opportunity. Although discrete perspectives on COVID-19 certainly hold value, Wen et al. [8] pointed out that interdisciplinary research can make a significant contribution to managing this global health crisis. Moreover, interdisciplinary study is widely considered a source of innovation and a worthwhile means of tackling complex problems. According to Terkenli $[9,10]$, the multidisciplinary field of landscape studies is ever evolving, consolidating gains and breaking ground in slow but 
steady steps. Terkenli [10] noted that it has been previously argued that the relationship between tourism and the landscape is irrevocable, uncontested, and even essential to tourism. The landscape is made up of a multitude of "modules" and "layers", as Bruns [11] pointed out, making it necessary to bring together as many different disciplines as possible.

The article seeks to understand public perceptions on city landscaping during the outbreak of COVID-19. Thus, this research discusses the theoretical aspects of city landscaping during the outbreak of COVID-19 and conducts an empirical study of the experiences of the Vilnius Pop-up Beach, located in Vilnius, Lithuania. The object chosen for the empirical research, the temporary Vilnius Pop-up Beach, as an alternative to compensate the mobility restrictions, was installed in Lukiškès Square. Lukiškès Square was formed in the green suburbs of Vilnius [12] and the image of the city center has changed considerably during its history, still keeping very strong political and public debates about the usage of Lukiškès Square.

This article is organized as follows: Literature Review, Materials and Methods, Research Setting, Results, Discussion, and Concluding Insights are presented in subsequent sections. The literature review is divided into three subsections: analyzing restrictions on the right to travel resulting from COVID-19; the right to the city and transformation; urban transformation. The section of Materials and Methods describes methods and data used, while the section of Research Setting presents the object and its context. The empirical results are presented in the Results section. The Discussion section discusses theoretical and empirical insights, and this article finishes with concluding insights.

\section{Literature Review}

As an introduction to the research topic, the theoretical part of this article analyzes the right to travel and COVID-19 (Section 2.1), discusses right to the city and transformation (Section 2.2), and examines urban transformation (Section 2.3).

\subsection{Right to Travel and COVID-19}

When speaking about the right to travel during the outbreak of COVID-19 and looking for solutions of how to realize this right, we should keep in mind that the fundamental and most important human rights, such as the right to health and the right to life, should be respected. The human rights to health and freedom of movement are fundamental and universal, and both rights create immediate obligations on states. The existence of these two rights in the context of migration and travel and, in particular, recommendations that limit active recruitment or promote self-sufficiency policies as part of an ethical code of practice do not compromise a state's ability to honor both of these rights. In summary, the tension between the two internationally accepted human rights remains, in large part, due to perception rather than being strictly dictated by human rights law [13].

COVID-19 also restricted the mobility of the Lithuanian people, as international travels were restricted; therefore, it was necessary to find ways of how to replace them within the country. Such needs were especially visible in the major cities. Therefore, new ways and solutions are being sought to compensate restrictions on people mobility. As an alternative, the city mayor of the Lithuanian capital Vilnius opened the temporary Vilnius Pop-up Beach.

It should be noted that the limitations related to the restriction of free movement and the right to travel are not a new phenomenon. For example, in July 1979, an outbreak of influenza after a prolonged stay aboard a commercial airliner in Alaska was reported. As Fricker and Steffen [14] noted, while unable to take off, the aircraft ventilation system was shut off. Toebes [15] noted that global mobility has only rarely resulted in a significant public health impact; lately, this was the case with HIV and SARS, which would have spread at a slower pace before the popularization of air travel. Baker [16] argued that travelers should be considered an integral part of the global surveillance network for emerging infections. 
An analysis of the legal literature and court cases reveals that there are also several violations regarding the restriction of rights related to the protection of national security and public health [17]. For example, in court decision I/A Court H.R., Matter of the Penitentiary Complex of Curado, Brazil (2016), the commission noted that Brazil had not presented a detailed plan to provide medical assistance to inmates with contagious diseases such as tuberculosis [18]. According to Page [19], the most difficult part of any quarantine law is determining the extent of protecting individual rights and liberties while keeping the public healthy and safe. It should be noted that the right to free movement of persons is fundamental, but it is not absolute. Article 3 of The Universal Declaration of Human Rights guarantees that everyone has the right to life, liberty, and security of person [20]. The security of all citizens, the right to life as a fundamental and indisputable right, and a safe environment must be ensured. Under Directive 2004/38/ec of the European Parliament and of the Council [21], "procedural safeguards should also be specified in detail in order to ensure a high level of protection of the rights of Union citizens and their family members in the event of their being denied leave to enter or reside in another Member State, as well as to uphold the principle that any action taken by the authorities must be properly justified" [21] (Art. 29). Under Art. 29, the only diseases that justify measures restricting freedom of movement shall be those with epidemic potential as defined by the relevant instruments of the World Health Organization, and other infectious diseases or contagious parasitic diseases if they are the subject to protection provisions applying to nationals of the host Member State.

Governments of most countries have increasingly sought to restrict the freedom of movement of individuals in response to COVID-19. The restrictions on travel have slowed, but not stopped, the spread of the pandemic, and the necessity and benefits of this health protection are outweighed by violations of international law. According to Art. 43 of the International Health Regulations, which are binding on all Member States of the World Health Organization, health measures "shall not be more restrictive of international traffic and shall not be more invasive or intrusive to humans than reasonably available alternatives" [22,23]. Meier et al. [24] suggested, in the context of public health measures such as social isolation and the effectiveness of contact tracing, the need for travel bans compared to less restrictive alternatives, thus avoiding global fragmentation and violation of international human rights. International human rights law, in particular the International Covenant on Civil and Political Rights (ICCPR), requires that restrictions on rights based on public health or national emergencies be lawful, necessary, and proportionate [25].

To summarize, the right to travel under international human rights law, in principle, protects and guarantees the lawful and free movement of every citizen throughout the country, and the right to leave any country. It should be noted that restrictions on these rights can only be imposed when they are lawful for a legitimate aim and when the restrictions are proportionate, including their consequences. COVID-19 is one reason for the implementation of legal travel bans and restrictions on the right to travel because these restrictions are intended to protect the health and possibly even the lives of citizens.

\subsection{Right to the City and Transformation}

As for the right to travel during the outbreak of COVID-19, we also need to discuss the right to the city and transformation for better possible solutions of implementation of this right. When talking about restrictions on the free movement of persons, alternative traveling possibilities should be examined. This includes local travel within the country, increasing the demand for places to visit, and methods to attract more visitors. This situation encompasses the right to the city. Manville et al. [26] noted that during this period, citizenship was perceived as a powerful political and legal instrument that united the city as a political community and allowed citizens to express the affairs of the city in exchange.

Calabi argued [27] that modern chronicles often describe urban squares and early markets, or land and building uses, that are characterized by specific changes in function. Veirier [28] explored the historical aspects of the city, noting how actions are limited when 
they focus only on buildings, without considering the inhabitants, networks, locations, and interactions with its wider area.

Lefebvre [29] (p.179) argued that the "Right to the City" is the right to "urban life, to renewed centrality, to places of encounter and exchange, to life rhythms and time uses, enabling the full and complete usage of... moments and places." The right to the city includes areas such as: public space and transport; citizens' rights to water; immigration and urban renewal; financial aspects; globalization and the consolidation of major cities; justice; spatial imagination; political aspects; and adaptation of urban squares to public needs, landscape planning, and change. Purcell [30] explained Lefebvre's [29] theory, arguing that the right to the city would restructure the power relations which underlie urban space, transferring control from the capital and the state to urban inhabitants. Purcell argued: "with respect to the right to the city, avoiding the local trap means we must move beyond a right to the city and think more in terms of a right to inhabit space" [31] (p.103). Harvey [32,33] defined the right to the city as the individual's freedom to use urban resources (including space, services, and infrastructure) and the ability to exercise collective power to reshape urbanization processes. Marcuse [34] argued that the right to the city implies both the protest of marginalized groups (poor, homeless, or persecuted) and groups that, while integrated into the existing system, fail to realize their full potential. The first group includes excluded social groups and the low-paid working class. In the second group of scholars, the representatives are alienated from the middle and upper classes, especially young people and members of the intelligentsia, artists, and officials. The frustration of both groups is that the city's services and initiatives do not meet the expectations and needs of these groups [35]. Shaw and Graham [36] discussed the concept of information rights in the city, which is useful for understanding the power of an information monopoly such as Google. The control of information monopolies, according to scientists, provides an opportunity to restore and manage the urban space itself. Lima et al. [37], in discussing the right to the city, noted the importance of regulating the use of urban property as a key tool for urban development, taking into account the collective good, the well-being of citizens, and sustainable development. According to Tavolari [38], the right to the city brings together the most diverse social actors, and this is despite the fact that the concept is given many meanings, namely, because of the ability to project so many meanings into the same expression. The strength of the right to a city lies in the fact that the concept is not limited by the academic community, public space, state, or international organizations. The concept of the right to a city is much broader [38].

Zeybekoglu [39] investigated the relationship between the transformation of cities and the right to the city. The researcher raised the challenges posed by modern urbanization, such as social exclusion, poverty, and environmental degradation. The author discussed the right to the city and its relationship to these global urban issues [39]. Thus, Lefebvre [29] noted that the production of urban space also means "reproducing the social relations that are bound up in it" [29] (p.39). For this reason, significantly more than planning is required of the physical space; "it involves producing and reproducing all aspects of urban life" [32] (p. 158). The right to the city involves two fundamental rights for urban inhabitants: the right to oeuvre (participation) and the right to appropriation. The right to participation asserts that inhabitants of the city must play a central role in all decisions contributing to the production of urban life. The right to appropriation is the right to physical access, presence, and use, and can be summarized as inhabitants' physical existence in the urban space [40].

Bertuzzi [41] highlighted the relationship between mega events and government structures and the right to the city, given the importance gained by the city during the years of mobilization. Siokas et al. [42] discussed the city right in an attempt to evaluate and analyze the strategic actions of the Greek municipalities from an internal and external perspective of a public authority. Results showed that most local authorities try to formulate a coherent framework to efficiently utilize available resources and enhance the productivity and quality of the services provided. 
The city right is closely related to modern and smart cities. According to Chourabi et al. [43] and Neirotti et al. [44], most modern cities attempt to align their innovative digital applications and various "smart" projects with a well-organized strategic policy and roadmap with clear targets, objectives, and roles. Kim et al. [45] found the significance of smart cities lies in not having technology itself but using technology with a novel approach to solve urban problems, enhance the quality of life for urban residents, and optimize government performance. Such an approach includes scientifically processing civic query data (including complaints, suggestions, and inquiries) about a city and planning the city such that its policies reflect its residents' voices to ensure "throughput legitimacy."

According to Marcuse [34], the right to the city includes people who are unable to meet their basic needs and exercise their fundamental rights; people who are excluded from the system and exploited by others; and those who are rejected and oppressed because of their social and cultural identity. The right to the city is not a set of individualistic, individual rights to some of the listed provisions and amenities of the existing legal system, but a collective and holistic right to say that that system would be better. Marcuse [34] explained the concept of the city of Lefebvre [29] as the future of the city and the right to the city. Contrary to the general understanding and interpretation of the city as an existing location with a physical reality and materiality, the concept of the future city implies an ideal urban society that implements "justice, democracy, full development of human potential or opportunities, for all according to their needs, for all according to their abilities, the recognition of human differences" [37] (p.193).

In summary, the Lefebvre [29] concept, applied decades ago, can be also adapted to today's cities, considering the latest urban trends and social transformations, the growing urban population, and new technologies, population needs, and expectations. There is no denying Lefebvre's [29] conviction that decision-making processes in cities need to be redesigned to involve the urban population more effectively in the decisions that shape their environment and, at the same time, that the urban landscape is still relevant to today's cities.

\subsection{Urban Transformation}

When analyzing urban landscaping, it is important to discuss urban transformation. There is a pressing need for alternative visions of urban life [46]. Additionally, it is important to mention that, in tourism studies, the interplay of tourism growth and urban transformations can be considered as a field of research that has been widely neglected for a long time and that has started to gain more importance only very recently [47]. In the living age of urban transformation, in which changes are taking place at an extremely rapid pace and no longer seem surprising, some of the problems facing cities today are unprecedented.

As noted by Roberts [48], urban transformation as an urban policy strategy can be described as "a comprehensive and integrated vision and action which seeks to resolve urban problems and bring about a lasting improvement in the economic, physical, social, and environmental condition of an area that has been subject to change or offers opportunities for improvement". Cohen [49] emphasized that urban transformation promotes economic growth, reduces poverty, and promotes inclusive human development. Cities develop and have the infrastructure needed to share knowledge and information. It should be noted that urban dwellers are often younger, more highly educated, and, at the same time, more demanding of various social services and entertainment. They are also more open to innovation and interesting solutions, such as an artificial beach in the town square, even if such a solution may stand out from the context of the urban landscape [50]. Alpopi and Manole [51], as the main goals of urban transformation, emphasized the transformation of public spaces, adapting to the needs of the population, the protection and renewal of historic areas, the improvement of living conditions in residential areas, and modernization of urban infrastructure. Urban transformation also poses many challenges to human development. It is estimated that nearly 40 percent of the world's urban expansions can take place in slums, which increases economic disparities and unsanitary conditions. In 
addition, poor urban infrastructure, such as unreliable electricity systems, congested roads and poor public transport, inefficient ports, and inadequate schools, reduces the competitiveness and economic prospects of cities [41]. Davies and Brooks discussed symbolic traditions and new material and their role in urban transformations [52]. Nofre et al. also agreed that the socio-cultural production of ideologies can have an important impact in urban transformation processes. Scientists are exploring the impact of urban night tourism and studentification for urban transformations [53]. Jackson et al. [54] analyzed how multi-sensory ethnography might influence and, at the same time, enrich urban transformation [54]. Balikci and Koylanm [55], meanwhile, explored the transformation of the city using the concepts of evolutionary economics as a process driven by people's desire to move up the social hierarchy through "costly signaling" or noticeable consumption rather than the desire to improve the functional quality of their housing [55].

People have been, and continue to be, attracted to cities by greater educational and employment opportunities, especially in the industrial and service sectors. Grübler and Fisk [56] noted that urban transformation is recognized as a positive force for economic growth and poverty reduction, and for human development. According to researchers, about 80 percent of the world's gross domestic product (GDP) is generated in cities. However, depopulation in many cities in Western Europe, Canada, and New Zealand does not appear to have had a negative impact on the quality of life of the population [57], the modernization of public services, or the promotion of a new governance of cooperation by strengthening the involvement of citizens and the local community [56].

In this article, we do not analyze in detail the means of resolving conflicts, but only want to draw attention to their importance in decision making related to urban landscaping. Nagenborg [58] suggested adapting a set of values that can be used in leadership and conflict resolution. A set of values can help determine how these conflicts are ultimately resolved, whether in terms of effectiveness, control, inclusion, or otherwise, in addition to informing urban policy. Speaking about a set of values for conflict solving in decision making, Bingham [59] emphasized the accessibility and predictability of the law, in addition to the transparency and accountability of public authorities, compliance with the rule of law, and the right to a fair trial.

When discussing urban transformation and its importance for urban landscaping, it is expedient to analyze urban activism, which has a significant influence on landscape formation. According to Domaradzka [60], the urban landscape is also influenced by the mobilization of the city, which manifests itself in various ways, such as the involvement of traditional civil society organizations, in addition to protest initiatives or political movements for environmental and social justice. As Bitusíková [61] emphasized, urban activism is now seen as an important area of urban governance processes and, at the same time, as part of landscape formation, and activists increasingly participate in urban politics and influence decision making through legal instruments and participatory practices. Frantzeskaki et al. [62] noted that, due to the huge wave of urban growth throughout history, more than half of the world's population lives in cities, and urban issues have become drivers of major policy and actors in civil society globally. Domaradzka [60] highlighted the increased mobility of the population and the growing interest of citizens in semi-public and public spaces focused on building new local or lifestyle communities. Burbank et al. [63] noted that urban regimes correspond to broad private-public coalitions, often involving actors from across the political spectrum. These usually arise in response to a crisis or, more generally, to revitalize the image of a city while promoting specific interests. According to Sassen [64], urban spaces are currently taking on a new meaning as venues for local meetings and performances, and for supporting new social and political realities. Keymolen and Voorwinden [64] also focused on the city as a political place. The researchers analyzed how both the technologies and the ideas on which smart cities are built displace trust and the rule of law as two important conditions for the city as a thriving political community. The authors also argued that current civic engagement in urban projects is not 
enough to create and contribute to a true political community and suggested evaluating active citizenship in the context of a smart city and urban landscaping [65].

Terkenli [66] argued that understanding and intervening in the landscape is based on human interrelationships and connections with our environment, taking into account the cultural context of the landscape, local features, and not necessarily respecting relevant Western conditions. Skaloš and Kašparová [67] also noted that the landscape has an indisputable cultural and historical value, although it does not contain any special natural or cultural objects, because it reflects the long-term relationship between people and the place in which they spent their entire lives. Researchers use the term "landscape memory", which in the opinion of the authors is strictly purposeful and quite metaphorical. A large part of the memory of the landscape consists of built-up areas and communications [67]. Another important factor that affects landscape formation is the freedom of the landscape, which can help draw attention to problematic associations of autonomy and limitation [68]. When discussing urban transformation and its importance for urban landscaping, it should be emphasized that the landscape interfaces with nostalgia. According to Adie et al. [69], nostalgia has been noted as being particularly heightened in times of change [70], wherein nostalgia is, in and of itself, an expression of loss [71]. Lowenthal [72] linked the origins of nostalgia with attachment to scenes from his childhood homeland and saw nostalgia as an exaggerated love for the past and a sense of the future. According to Lowenthal, nostalgia can help to feel a deeper connection with the past, and people's associations and memories are important for shaping the landscape [72]. Nostalgia is regarded as an intrinsic motivation, which drives tourists to seek a past experience [73]. Various urban transformations (although temporary as under the object of the article research) can be used for searching for such kinds of experiences.

In summary, the limitations of the right to travel during the outbreak of COVID-19, when searching for alternative traveling possibilities, become apparent through the right to the city and urban transformation. After discussing the theoretical aspects, such as the right to the city and the effect of urban transformation on the urban landscape, we present the empirical research of the experiences of the changing landscape in Lukiškeis Square, Vilnius, which was transformed into the temporary Vilnius Pop-up Beach.

\section{Materials and Methods}

Thematic analysis was selected for the empirical research. According to Clarke and Braun [74-76], thematic analysis, as a foundational method for qualitative analysis, is flexible, and it is not limited to any particular theory or system. This allows it to reveal the experiences of the changing landscape of the transformation of Lukiškès Square into the temporary Vilnius Pop-up Beach. Clarke and Braun [76] viewed thematic analysis as theoretically flexible and suited to a wide range of research interests and theoretical perspectives, and useful as a "basic" method, because it works with a wide range of research questions, from those about people's experiences or understandings, to those about the representation and construction of particular phenomena in particular contexts. Braun and Clarke [74] pointed out that, since the publication of their original article in 2006, "thematic analysis has gained hugely in popularity, and entered the "canon" as a recognizable and reputable method of qualitative analysis, evidenced by its inclusion in volumes such as this".

The flexibility of thematic analysis, as Braun et al. [75] noted, means that it can be used with a wide range of different research designs and data collection methods and that it has no "ideal" data type. Data for the thematic analysis of the current study were selected from public reactions and feedback found in official media pages and other media sources [77-81], altogether including in the analysis 481 public opinions and feedback responses (the names of participants, whose reactions (public opinions and feedback) were used as empirical data, were renamed, using combinations of capital letters and numbers, for example, F3 or E5, etc.). Analyzed data from media sources opened up the view of various public opinions and feedback responses, belonging to various groups, such as: 
policymakers, local authorities, architects, regular citizens, etc. The research was conducted during the landscaping process, in actual time, when the Vilnius Pop-up Beach was in action (June-September, 2020).

According to Braun and Clarke [74], thematic analysis is a method for identifying, analyzing, and reporting patterns (themes) within data. Thus, six phases of thematic analysis by Clarke and Braun and Braun and Clarke $[74,76]$ were used for this empirical study: familiarization with the data, generating initial codes, searching for themes, reviewing themes, defining and naming themes, and writing up or producing the report (Figure 1).

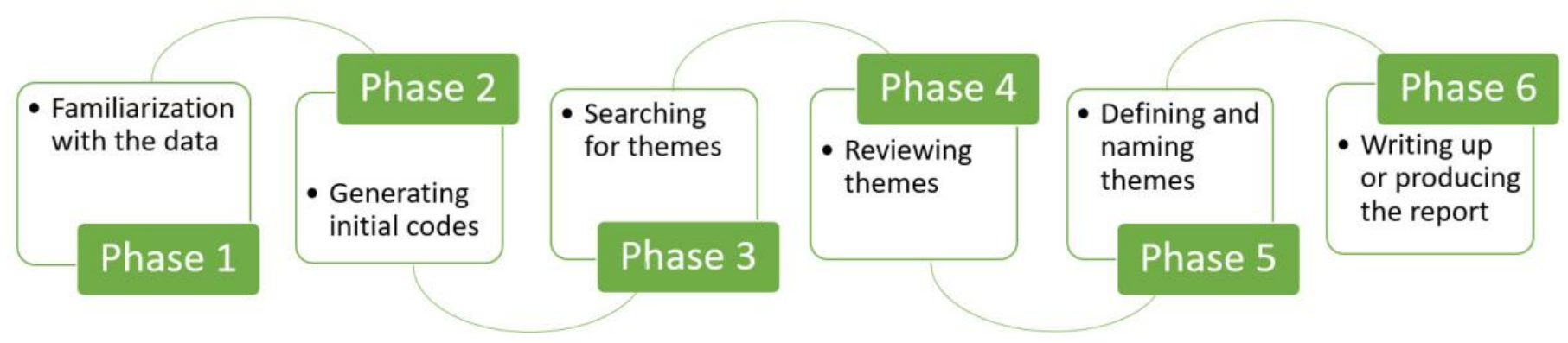

Figure 1. Phases of thematic analysis (by Clarke and Braun and Braun and Clarke $[74,76]$ ).

The analysis started from the first phase, "Familiarization with the data". This process started when the authors began to notice and look for patterns of meaning and issues of potential interest in the data. Thus, collected public opinions and feedback were then read and re-read several times, i.e., the authors familiarized themselves with the empirical data by reading and revisiting the data found in public opinions and feedback. The second phase of thematic analysis, "Generating initial codes", started when the authors read and familiarized themselves with the data and, when building on the notes, generated an initial list and ideas about what was in the data and what was interesting about them. Thus, the authors coded the relevant data, seeking to find initial codes. The third analysis phase named by Clarke and Braun [76], "Searching for themes", allowed the authors to re-focus the analysis at the broader level of themes, rather than codes, involved revisiting all relevant data that are similar to certain codes to form the initial themes, i.e., trying to combine different codes that may have been very similar or may have been considered the same aspect within the data. During the fourth phase of thematic analysis, "Reviewing themes", the authors crosschecked the chosen themes, trying to cohere the data within themes together meaningfully, while finding clear and identifiable distinctions between themes. At the end of this phase authors found the clear idea of the various themes and how they could fit together. During the fifth phase, "Defining and naming themes", the authors clearly defined the themes and named them, trying to give the reader a sense of what the theme was about. As the goal of this phase was to be able to "clearly define what your themes are and what they are not" [74], in seeking this goal, the authors focused on defining each theme, trying to identify the essence of the themes. Therefore, the authors constructed fulfilled themes, explaining their meaning and defining each theme, which should reflect the overall story of the research topic. During the sixth phase, "Writing up or producing the report", the authors had a set of fully worked-out themes. The above five stages made it effective for the authors to understand and to study and re-study the qualitative data results to combine the analytic narrative and extracted data by presenting to the reader full thematic analysis and the significance of each theme to the research topic.

According to Braun and Clarke [74], thematic analysis here involved a constant moving back and forward between the entire dataset, the coded extracts of data that were analyzed, and the analysis of the data that were produced; thus, writing here was an integral part of analysis, not something that took place at the end. Thematic analysis is understood as an active process, and thus, although it is described as a method-as a way to analyze data, rather than a whole framework - these steps must not be followed in 
robotic repetition, without thought and deliberation, and without conscious choices, action, and thinking [74]. Analysis here was not viewed as a linear model; rather, analysis was viewed as a recursive process. Thus, after presenting the research setting, the results of thematic analysis, the main themes, and subthemes are presented in the Results section.

\section{Research Setting}

As previously mentioned, the setting for this research into the experiences of a changing landscape is the temporary transformation of Lukiškès Square, Vilnius, into the Vilnius Pop-up Beach (Figure 2). The debates about the usage of Lukiškès Square have been very active at times, especially during the last 30 years of Independent Lithuania. With the intensification of the surrounding settlement, the trapezoidal shape of the space was evident, buildings of substantial architectural style emerged, and the functionality of the space changed: broad suburban fields, used as a market place, gradually decreased, and the planting of trees in lines as a space perimeter resulted in the appearance of representativeness [12]. During the Tsarist occupation of Russia, the space was even used for the demonstration during the 1863 rebellious execution. Polish military parades were conducted there, and in the Soviet era, the area was turned into an ideological square in front of the KGB palace (Committee of State Security) in which a Lenin monument was built. Following the restoration of Lithuania's independence, dismantling of the statue symbolized the final victory of freedom [12]. It appeared that the debate about Lukiškès Square had ended and that the new image should be universally accepted [15]. Thus, the main objective and challenge here is to reflect the expectations of all social groups in a huge public space [14]. There is a long history related to the establishment of the new public monument of Lukiškès Square [12]. It is important to notice that in Lithuania, there are, named as representative squares, the main or largest squares in the central cities or squares which are declared as such authorities. For example, the resolution of 11-02-1999 No. VIII-1070 "Regarding Lukiškès in the state capital Parliament (Seimas) has decided: 1. Lukiškès Square in Vilnius is being formed as the main one representative state square of Lithuania with freedom fighting memorial accents. 2. Lukiškès Square in Vilnius, as historically formed integrated urban space must perform state representative and at the same time social function" [82]. Design decisions must cover and reconcile two functions - to incorporate the building at Gedimino ave. 40 and Auku street and evaluate the Pamenkalnio perspective of urban solutions [82]. Even though most civic and political communities, as well as the public, welcomed this timely and highly symbolic step, the development of the square as a public space was slow and largely ineffective [83]. Thus, the competitions for Lukiškès Square were associated with many meaningless discussions and disputes, as well as angry and categorical speeches, which ended without satisfactory results [83]. Thus, the representative squares, as well as the monuments, have become the subject of political debate and political disagreement [84]. The squares havingideological accents (monuments), in many cases, are difficult to reconcile in real life, not in declarations or resolutions of parliament, demonstrating their multifunctional purpose [85].

It is important to note that the first wave of quarantine in the country, which was introduced in Lithuania in mid-March, was lifted on 17 June, but some summertime restrictions remained. Use of face masks in public after 17 June was not mandatory, but masks still had to be worn in shops, public transportation, museums, and other public indoor spaces. By the end of June, outdoor events could be limited to 700 people, and later to 1000 people. There were no more than 150 and 200 people at the indoor events after 1 July. Restrictions on international travel also remained [86].

Thus, the so-called open beach was opened in Lukiškès Square in June. The so-called beach was made up of 300 cubic meters of sand. The city authorities called this beach a gift to citizens and guests of the city instead of lost vacation due to the coronavirus [86]. On June 23 2020, the city mayor of Vilnius opened the temporary Vilnius Pop-up Beach and noted "If people of Vilnius cannot go to the sea, then the sea will come to Vilnius". Thus, Lukiškès Square, the largest square in the city, was turned into an "Open Beach" (Figure 2). 
White sand, wooden paths, sun loungers, a lifeguard tower, and changing booths invited visitors to experience Vilnius as a summer holiday place.

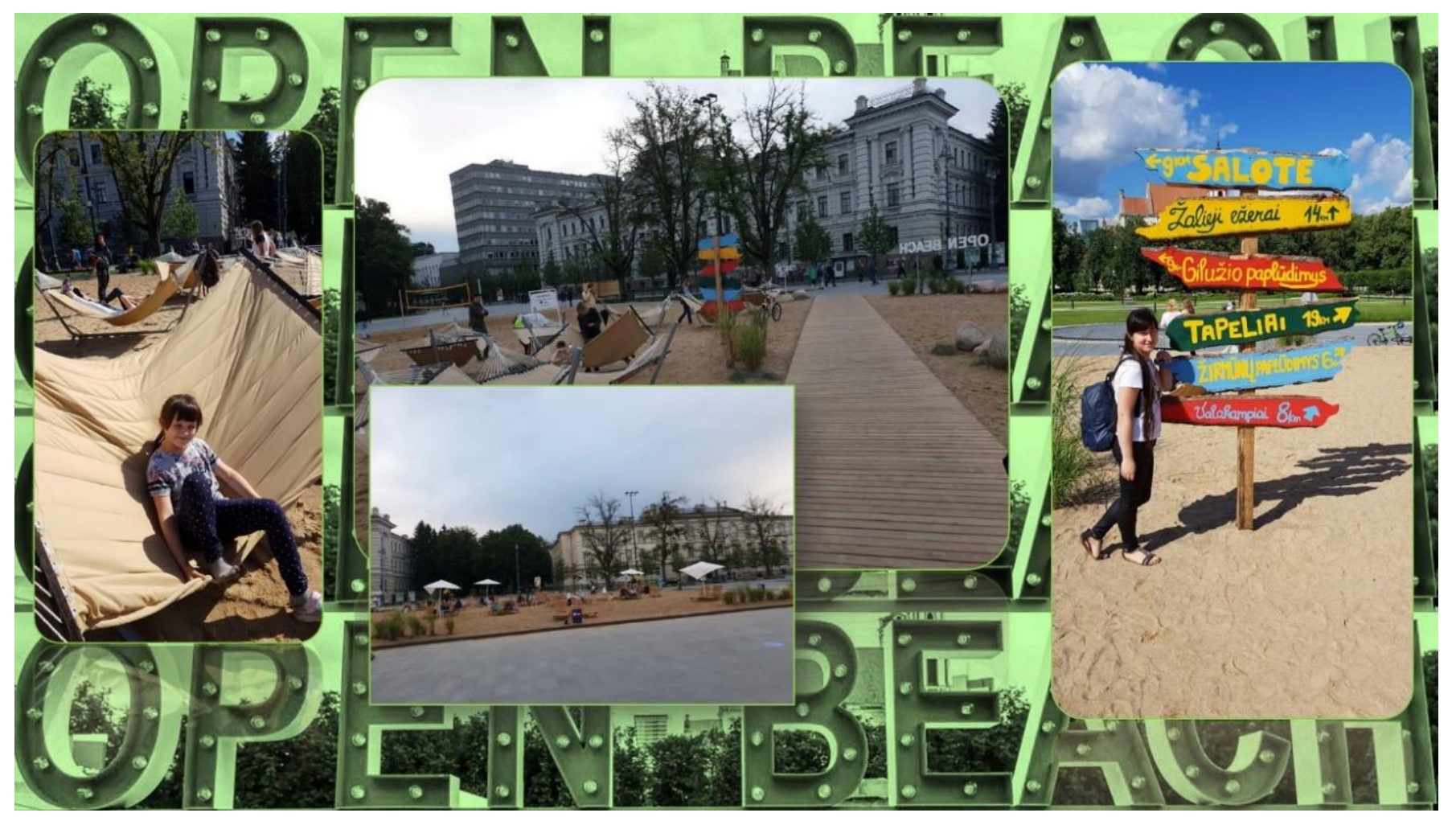

Figure 2. Photo collage of the Vilnius Pop-up Beach (Photo collage made by the authors).

The project creatively deals with one of the hardest consequences of quarantinerestricted freedom to travel and strongly affected vacation plans [12]. "We could not ignore the fact that many people had to drastically change their already planned vacation due to quarantine", said the mayor. Since the city had previously proved itself open for creative solutions in difficult times, the mayor said this idea was no exception: "The popular seaside resorts of Southern Europe are not easily accessible at the moment, and our Baltic Sea beaches will be overpacked this summer. That's why we needed a solution to help people recoup some of that vacation vibe on Vilnius' very own beach" [87]. However, following the initiative of the Vilnius mayor, the artificial beach installed in Lukiškès Square has received ambiguous evaluations and numerous criticisms. This artificial beach positioned in the city center, including sunbeds, sand, and a changing cabin, has been the subject of significant discussion among the public, politicians, and architects.

According to Linden, architect Čaikauskas [88] noted that, although the water near the sand gushes only from stationary fountains, the stormy sea of texts and opinions that spilled into the public space testifies that the development had a significant effect. Both the State Commission for Cultural Heritage, whose members consider that such a beach is incompatible with the historical and memorial significance of the location, and the State Commission for the Lithuanian Language (VLKK), which was struck by foreign inscriptions on the beach, expressed their opinion. The head of VLKK called the beach in Lukiškès Square in the capital a "moral crime for the Lithuanian language" due to the English inscriptions. The Seimas quickly reacted to the beach in Lukiškès Square, adopting the Law on the Memorial Status of Lukiškès Square in Vilnius, which established that it is the main representative square of the Lithuanian state and was formed in memory of the struggles for freedom. These memorial accents reflect the struggle for the independence of Lithuania and the memory of the fighters who died in 1863-1864, as the place of execution of the rebels, and the commemoration of this uprising. This law relating to Lukiškès Square, 
adopted by the Seimas, was also signed by the President of the Republic of Lithuania. The Lithuanian parliament, Seimas, subsequently passed a law, designating the square as a site of commemoration of the fighters for the country's independence and outlawing any activities that offended "good morals". However, Vilnius authorities-who argued that the law violated the city's self-governance-left the beach in place until the end of summer, as planned [89].

Dismantling works on the Vilnius Pop-up Beach began on the first days of September, when the 300 cubic meters of sand, that covered 1660 square meters of the square, were transported to river and lake beaches in Vilnius [89]. Furthermore, Lukiškès Square regained its former landscape view. Therefore, it seems important to study the public perceptions that emerged during this temporary transformation of Lukiškès Square more deeply.

Therefore, as it was mentioned, seeking to reveal the experiences of the changing landscape of the transformation of Lukiškès Square into the temporary Vilnius Pop-up Beach, a qualitative approach and thematic analysis were selected for the study. Thus, the results of thematic analysis, the main themes, and subthemes are presented in the next section.

\section{Results}

The thematic analysis of public opinion in the media, and public reactions and feedback about the Vilnius Pop-up Beach resulted in the identification of several themes: "Nostalgia for heroic landscape", "Changing memory landscape", and "Enjoying the landscape of freedom".

The first theme, "Nostalgia for heroic landscape", connects the following subthemes: "Experiencing the heroic memory", "Experiencing the loss of heroic memory", and "Intersection of contradictory experiences".

The subtheme "Experiencing the historic memory" presents the idea of the clarity of the understanding of the historical landscape: "Some commentators understand neither the purpose of the square nor the meaning of the characters. After all, elementary decency and common sense. Maybe enough to argue? It was complete nonsense to transport sand to the square; in the historic square to hold all kinds of experiments at the place and point. Where have you grown up, in what families if you don't understand the essentials?" (F9). The subtheme "Experiencing the loss of heroic memory" opens up the discussion about the importance of bringing back the memory: "Carefully I would go to that square in your place - it brings back the memory. If you have forgotten sins or experiences that you have already been lucky enough to forget, you better not go there!" (F7). This subtheme also deepens the understanding about the importance of responsibility: "Good order in our country that no one is responsible for the stupidity in the most honorable place of the capital. There is no need to cry every day about past events, but history needs to be known and respected" (F3). The discussion here reveals various layers, even the sarcastic questioning: "Surprisingly, I was always sure that we remember the struggles for freedom and the suffering of the people throughout the territory of Lithuania. A demonic place is a beach, maybe you should think about closing all the beaches because we lose memory when we go there?!" (F8). The subtheme "Intersection of contradictory experiences" points to a difficult intersection with controversial landscaping: "It didn't fit in that stretch to that board with partisan relics. Look across the street at the monument to the victims of Stalinism, already stretching across the street. Same as having a funeral in one room, a wedding in another. After all, there are other places for beach fun" (E5).

The second theme "Changing memory landscape" is presented through these subthemes: "Doubting the semantic meaning" and "Not anymore just a memorial square". Since the beach is normally understood as a fun place near the water, the subtheme "Doubting the semantic meaning" indicates the public's attention and its reflections about a beach "as a place to have fun is a great idea. But by the river, where the water, greenery. After transporting a ton of sand to the square, Vilnius mayor first of all ignores the elementary 
established directions of the functional flows of Lukiškès Square and accesses, a certain system of semantic communication of the area" [78]. Another reflection discusses a different semantic meaning, presented as another sarcastic expression: "we enriched the language: there is an electrical installation, the building installation is another installation, there was also the installation of additional sand, and bringing and pouring sand is an event, and I thought it would work. Significant. Everyone realized that this is a high-end beach. And without thinking about hygiene, plunged into pleasures" (F2). The subtheme "Not anymore just a memorial square" reveals the understanding of the changing meaning of the square: "Leave the main Vilnius market square alone! It was no longer a memorial square-it was only when Lenin was standing. The square and the park are dedicated to all the town's people and their guests, which was perfectly arranged during the years of mayor and his team. Determining the purpose, memorials and accents of one square by law violates the simplest principles of legislation, so no matter what city or square it is" (E6). Thus, the subthemes "Doubting the semantic meaning" and "Not anymore just a memorial square" show the variety of meanings of the changing memory of the landscape.

The third theme, "Enjoying the landscape of freedom", is presented through subthemes such as "Happy support", "Happy cities", "Happy landscaping", and "Freedom as happiness". The subtheme "Happy support" presents the positive side of the Pop-up Beach: "Probably for the first time in 30 years of Lithuania's independence, when I support public notes in English. Fountains, half-naked EU/NATO citizens and English words right in front of the former KGB building are the best thing that could have happened to this square. I belong to a generation that still managed to see a sculpture of Lenin in this place. Since then, the square has changed beyond recognition. To the good side" (E1). The subtheme "Happy cities" shows the examples of other countries' experiences about the use of the city landscape: "Berlin did the same in one of the main squares this year, and even the bar was selling alcohol. For some reason no one was crying there, people were happy to have a place to relax in the city center" (F4). The subtheme "Happy landscaping" describes the positive energy of the beach idea: "I lost sight of that beach rush and still didn't really understand what that beach got into. I didn't interfere with what's getting stuck, but getting stuck. I realized that some people lack monuments and monuments in Vilnius, others stand in the way that the navel is bare, as if there were no of them, and in such weather. I realized that there are outrageous non-Lithuanian notes. I read that it's bad that the square is full, and big events can't yet take place legally. But I didn't find it as bad as the beach. Maybe what did I miss?" (E2). The subtheme "Freedom as happiness" represents the understanding of the changing meaning of the memory of the landscape and freedom: "The fact that this beach is located in this place is an association, at least for me and many, that we can finally enjoy our freedom. Because there was a lot in this place, there were demonstrations of both totalitarian regimes, there were really attempts to do bad things, but today we see happy people and we can celebrate that we are winners in the struggle for our freedom" (E3).

The thematic analysis of the public opinion in media and public reactions to the Vilnius Pop-up Beach led to a discussion of the themes: "Nostalgia for heroic landscape", "Changing memory landscape", and "Enjoying the landscape of freedom", thus showing the controversy of the changing city landscape. This is discussed more fully in the following section.

\section{Discussion}

According to Jasiński [5], the outbreak of the COVID-19 pandemic and the associated changes in the functioning of the community and cities have necessitated a new approach. It is also necessary to make redesigns in the public space from a security point of view, given the many costs involved in antivirus restrictions. A city is a creation, as Jasiński [5] noted, and the space is constantly transforming, adapting to different economic conditions and meeting various social needs. According to Butkus [90], the mutation of the city has a form and the birth of the city is an event. Rubavičius [91] noted that the guidelines for 
urban identity and redevelopment are determined by the accumulated symbolic capital. Thus, as architect Grunskis [92] noted, the concept of urban public space is now clearly fixed and defined. However, society's expectations of public spaces and their different types are changing, and this is happening much more intensively. Grunskis [93] argued that town communities should participate in the process of the formation of town public spaces. Thus, the discussion about the experiences of the city landscape is presented via discussion of the themes of the empirical study: "Nostalgia for heroic landscape", "Changing memory landscape", and "Enjoying the landscape of freedom".

\subsection{Nostalgia for Heroic Landscape}

Nostalgia for heroic landscape: Butkus [94] noted that several cultural layers are now "rewritten" on top of a new, unidentifiable cultural layer, "nostalgic historicism". Thus, thematic analysis of Vilnius Pop-up Beach experiences shows the importance of "nostalgic historicism" with the theme "Nostalgia for heroic landscape". Nostalgia naturally involves as a comparison between past and present circumstances [95]. As a process of remembering that is overtly, and often unashamedly, emotional, as Smith et al. [96] noted, nostalgia is an important phenomenon in understanding how the past is both brought to bear on the present and on the development of social and political agendas for the future. Moreover, Palmberger [97] argued that the memories around an idealized past can become powerful tales put forward in support of a shared future and in concrete cross-border interactions to establish common ground. Furthermore, the nostalgic experience may embrace a conflicting emotional state [98]. According to Gupta et al. [99], emplaced within histories and geographies of neighborhood change, nostalgia creates "affective landscapes" through which residents invoke their closeness to past landscapes of abundance and involvement in community making.

\subsection{Changing Memory Landscape}

It should be noted that the essential theory formed by Lefebvre [29] in 1968 and the theme "Changing memory landscape" are connected. The Lefebvre theory [29] is the basis and can be further developed in this context by incorporating more recent trends of globalization and urban development, such as landscape change and formation, changing the purpose of urban squares, and adapting them to current tourists and local population needs. In discussion of the changes in the formation of the urban landscape, we can ask whether we can think of the right to the city as a solution to the problems in the urban space arising from urban regeneration projects and the abstract space's hegemony on the social space? Suggested in 1967 by Henri Lefebvre [29], the idea of the right to the city places emphasis on the "need to restructure the power relations that underlie the production of urban space, fundamentally shifting control away from capital and the state and toward urban inhabitants" [29] (p. 26).

\subsection{Enjoying the Landscape of Freedom}

The right to a city is based on the protection and strengthening of the rights of all residents, especially the poor, ethnic-religious-cultural minorities, refugees, immigrants, nomads, people with disabilities and those at risk of health, and perpetrators of violence, as well as the vulnerable, such as the elderly, women, and children [100]. According to Cohen [49], the city is a place where entrepreneurship and technological innovation can flourish because the city has a well-educated workforce and a concentration of business. Thus, the third theme from the empirical analysis, "Enjoying the landscape of freedom", can be connected here. With regard to restricted freedom to travel in the context of urban landscaping, we share Marcuse's [34] view that the right to the city must include people who are unable to meet their basic needs and exercise their fundamental rights, people who are excluded from the system and exploited by others, and those who are rejected and oppressed because of their social and cultural identity [34]. 
Thematic analysis of public opinion in media public reactions about the Vilnius Popup Beach provoked the discussion themes: "Nostalgia for heroic landscape", "Changing memory landscape", and "Enjoying the landscape of freedom", which were revealed as a part of a conflicted debate. Thus, when we talk about key decisions related to the right to a city in the context of urban landscaping, it should be emphasized that these decisions need to be made in an urban environment, and adaptation of urban spaces and squares for the needs of society is represented by the term "conflict" [101]. It should be noted that, in this context, conflict therefore does not have a negative undertone, nor does it imply physical violence. This term aims to highlight and, at the same time, strengthen the process of political life in the city, when different interests have to allocate limited resources and space to create a common environment [101]. According to Čaikauskas [88], the current situation thirty years after the restoration of freedom and the independence of Lithuania shows that the society is still maturing. Differences in individual values are far from disappearing and may possibly be reignited. It must be realized that the meaning of symbols is an important part of the influence of the subconscious; symbols cannot be treated as mere formal objects that can be interpreted subjectively, according to someone's individual will, under the guise of slogans of artistic freedom of expression. Furthermore, nostalgia should be respected, thus linking the origins of Lowenthal's [72] view as the attachment to scenes from his childhood homeland to nostalgia seen as an exaggerated love for the past and a sense of the future.

Thus, the thematic analysis of public opinion about the Vilnius Pop-up Beach revealed the themes "Nostalgia for heroic landscape", "Changing memory landscape", and "Enjoying the landscape of freedom" and opened up a broader and deeper understanding of public perceptions on city landscaping during the outbreak of COVID-19. The analysis of this particular case revealed the universal travel perceptions and allowed experiencing traveling during the outbreak of COVID-19 as an alternative travel possibility. At the same time, public opinion and reactions, expressed when writing feedback about the controversy of the Pop-up Beach, thus engaging in the public discussion, allowed the development of unforeseen virtual travel experiences, even not traveling, just reflecting. According to Heatherington et al. [102], "the telling of alternative, and sometimes unforeseen, narratives, can contribute to an understanding of how the past has shaped the present and how both might in turn shape a future".

However, the study was also faced with limitations. Due to the flexibility of thematic analysis, allowing for it to be used with a wide range of different research designs and data collection methods and for it to have no "ideal" data type, the data for the current study were selected from public reactions and feedback found in official media pages and other media sources. Due to the chosen type of data, the authors might not have been able to uncover other important layers of the studied phenomena. Thus, in future research, including various other data sources such as interviews, observations, and focus group discussions would allow exploring new meanings and developing new insights.

\section{Concluding Insights}

The article revealed the understanding of public perceptions on city landscaping during the outbreak of COVID-19. The theoretical aspects: the right to travel and COVID19 , right to the city and transformation, and urban transformation, and also the empirical study of the experiences of the Vilnius Pop-up Beach, Lithuania, as a temporary urban transformation, showed the interaction of public perceptions on city landscaping. The theoretical background disclosed the limitations of the right to travel during the outbreak of COVID-19, when searching for alternative traveling possibilities, which become apparent through the right to the city and urban transformation. Therefore, the empirical study and thematic analysis on public perceptions about the Vilnius Pop-up Beach identified the themes: "Nostalgia for heroic landscape", "Changing memory landscape", and "Enjoying the landscape of freedom", thus revealing the controversy surrounding the changing city landscape. Therefore, theoretical and empirical insights showed that the various 
experiences (such as: nostalgia, changing memory, freedom, and joy) and phenomena (such as: urban transformation and the outbreak of COVID-19, alternative traveling) should be seen as the transformative practices of city landscaping. Additionally, it is important to point out that public perceptions should be heard and respected when considering the unique landscape of the past, present, and future and its impact on city memories. The results of this research highlight the importance for future sustainable landscape development to pay attention to the uncovered experiences expressed in public opinions. Thus, possible directions for future research should include more in-depth explorations on alternative travel experiences, looking for possible uncovered, unforeseen, sensitive, and meaningful travel experiences, which emerged during the outbreak of COVID-19.

Author Contributions: Conceptualization, R.P. and D.P.; methodology, R.P. and D.P.; data curation, R.P. and D.P.; writing — original draft preparation, R.P. and D.P.; writing—review and editing, R.P. and D.P. Both authors have read and agreed to the published version of the manuscript.

Funding: This research received no external funding.

Conflicts of Interest: The authors declare no conflict of interest.

\section{References}

1. Wintle, T. COVID-19 and the City: How Past Pandemics Have Shaped Urban Landscapes. CGTN. 2020. Available online: https:/ / newseu.cgtn.com/news/2020-07-08/COVID-19-and-the-city-How-past-pandemics-have-shaped-urban-landscapesQCFjZLBIxG/index.html (accessed on 25 September 2020).

2. Hooper, M. Pandemics and the Future of Urban Density: Michael Hooper on Hygiene, Public Perception and the "Urban Penalty". Harvard University Graduate School of Design. 2020. Available online: https:/ /www.gsd.harvard.edu/2020/04/havewe-embraced-urban-density-to-our-own-peril-michael-hooper-on-hygiene-public-perception-and-the-urban-penalty-in-aglobal-pandemic/ (accessed on 18 November 2020).

3. Newman Leigh, G. Reimagining the Post-Pandemic City. 2020. Available online: https://architectureau.com/articles/ reimagining-the-post-pandemic-city/ (accessed on 12 September 2020).

4. Hall, C.M.; Scott, D.; Gössling, S. Pandemics, transformations and tourism: Be careful what you wish for. Tour. Geogr. 2020, 22, 577-598. [CrossRef]

5. Jasiński, A. Public space or safe space-Remarks during the COVID-19 pandemic. Czas. Tech. 2020, 117, 1-10. [CrossRef]

6. Sigala, M. Tourism and COVID-19: Impacts and implications for advancing and resetting industry and research. J. Bus. Res. 2020, 117, 312-321. [CrossRef] [PubMed]

7. Strielkowski, W. International Tourism and COVID-19: Recovery Strategies for Tourism Organisations. Preprints 2020, 2020030445. [CrossRef]

8. Wen, J.; Wang, W.; Kozak, M.; Liu, X.; Hou, H. Many brains are better than one: The importance of interdisciplinary studies on COVID-19 in and beyond tourism. Tour. Recreat. Res. 2020. [CrossRef]

9. Terkenli, T. Landscapes of Tourism: A Cultural Geographic Perspective. Tour. Environ. 2000, 179-202. [CrossRef]

10. Terkenli, T.S. Landscapes of Tourism. In The Wiley Blackwell Companion to Tourism; Wiley: Hoboken, NJ, USA, 2014; pp. 282-293.

11. Bruns, Landscape, towns and peri-urban and suburban areas. In Reflections and Proposals for the Implementation of the European Landscape Convention; Council of Europe Publishing: Strasbourg, France, 2012; pp. 9-48.

12. Lukiškes square. Available online: https://archello.com/project/lukiskes-square. (accessed on 14 September 2020).

13. Honouring the Human Rights to Health and Freedom of Movement Realizing Rights. Global Policy Advisory Council Secretariat, Health Worker Migration Initiative 7 May 2009. Available online: https://www.who.int/workforcealliance/about/taskforces/ migration/MigrationTaskForce_techbrief.pdf (accessed on 10 July 2020).

14. Fricker, M.; Steffen, R. Travel and public health. J. Infect. Public Health 2008, 1, 72-77. [CrossRef]

15. Toebes, B. Human rights and public health: Towards a balanced relationship. Int. J. Human Rights 2015, 19, 488-504. [CrossRef]

16. Baker, D.M.A. Tourism and the Health Effects of Infectious Diseases: Are There Potential Risks for Tourists? Int. J. Saf. Secur. Tour. Hosp. 2014, 1, 1-17.

17. Compendium. Lithuania 2.9. 2019. Available online: https://www.culturalpolicies.net/country_profile/lithuania-2-9/ (accessed on 14 September 2020).

18. I/A Court H.R. Matter of the Penitentiary Complex of Curado Regarding Brazil. Provisional Measures. Order of the InterAmerican Court of Human Rights of 23 November 2016. Available online: http://www.stoptb.org/assets/documents/ communities/TB\%20Human\%20Rights\%20and\%20the\%20Law\%20Case\%20Compendium\%20(First\%20Edition).pdf (accessed on 30 July 2020).

19. Page, E.M. Balancing Individual Rights and Public Health Safety during Quarantine: The U.S. and Canada. Case Western Reserve. J. Int. Law 2007, 38, 517. 
20. Universal Declaration of Human Rights, Art. 13. 1948. Available online: https://www.un.org/en/universal-declaration-humanrights / (accessed on 14 January 2020).

21. Directive 2004/38/EC of the European Parliament and of the Council of 29 April 2004 on the Right of Citizens of the Union and Their family Members to Move and Reside Freely within the Territory of the Member States Amending Regulation (EEC) No 1612/68 and Repealing Directives 64/221/EEC, 68/360/EEC, 72/194/EEC, 73/148/EEC, 75/34/EEC, 75/35/EEC, 90/364/EEC, 90/365/EEC and 93/96/EEC. Available online: https:/ / eur-lex.europa.eu/legal-content/EN/TXT/?uri=CELEX:32004L0038 (accessed on 10 May 2020).

22. WHO. Director-General's opening remarks at the media briefing on COVID-19-11 March 2020. Available online: https://www. who.int/dg/speeches/detail/who-director-general-s-opening-remarks-at-the-media-briefing-on-covid-19---11-march-2020 (accessed on 10 May 2020).

23. WHO. New COVID-19 Law Lab to provide vital legal information and support for the global COVID-19 response, 22 July 2020. Available online: https:/ / www.who.int/news-room/detail/22-07-2020-new-covid-19-law-lab-to-provide-vital-legalinformation-and-support-for-the-global-covid-19-response (accessed on 26 July 2020).

24. Meier, B.M.; Habibi, R.; Yang, Y.T. Travel restrictions violate international law. Science 2020, 367, 1436. [CrossRef] [PubMed]

25. Taylor, P. Article 12: Freedom of Movement of the Person. In A Commentary on the International Covenant on Civil and Political Rights: The UN Human Rights Committee's Monitoring of ICCPR Rights; Cambridge University Press: Cambridge, UK, 2020; pp. 325-353. [CrossRef]

26. Manville, P.B. The Origins of Citizenship in Ancient Athens; Princeton University Press: Princeton, NJ, USA, 1990.

27. Calabi, D. The Market and the City Square, Street and Architecture in Early Europe; Routledge: London, UK; New York, NY, USA, 2016.

28. Veirier, L. Historic Districts for All: A Social and Human Approach for Sustainable Revitalization; brOchure Designed for Local Authorities. 2008. Available online: https://unesdoc.unesco.org/ark:/48223/pf0000158331 (accessed on 5 September 2020).

29. Lefebvre, H. Le Droit à la Ville, Suivi de Espace et Politique. L Homme et la Société 1967, 6. [CrossRef]

30. Purcell, M. Citizenship and the right to the global city: Reimagining the capitalist world order. Int. J. Urban Reg. Res. 2003, 27, 564-590. [CrossRef]

31. Purcell, M. Excavating Lefebvre: The right to the city and its urban politics of the inhabitant. Geo J. 2002, 58, 99-108. [CrossRef]

32. Harvey, D. The right to the city. Int. J. Urban Reg. Res. 2003, 27, 939-941. [CrossRef]

33. Harvey, D. The right to the city. New Left Rev. 2008, 53, 23-40.

34. Marcuse, P. From critical urban theory to the right to the city. City 2010, 13, 185-197. [CrossRef]

35. Margier, A.; Melgaço, L. Whose Right to the City? Urban Environ. 2016, 10, 1-7.

36. Shaw, J.; Graham, M. An Informational Right to the City? Code, Content, Control, and the Urbanization of Information. Antipode 2017, 49, 907-927. [CrossRef]

37. Lima, E.G.; Chinelli, C.K.; Guedes, A.A.; Vazquez, E.G.; Hammad, A.W.; Haddad, A.N.; Soares, C.P. Smart and Sustainable Cities: The Main Guidelines of City Statute for Increasing the Intelligence of Brazilian Cities. Sustainability 2020, 12, 1025. [CrossRef]

38. Tavolari, B. The Right to the City: Conceptual transformations and urban struggles. Rev. Direito Práxis 2020, 11, 470-492. [CrossRef]

39. El Helou, M.A. Towards A Post-Traumatic Urban Design That Heals Cities' Inhabitants Suffering From PTSD. Contemp. Urban Aff. 2020, 4, 79-90. [CrossRef]

40. United Nations, Department of Economic and Social Affairs, Population Division. World Urbanization Prospects: The 2014 Revision. (ST/ESA/SER.A/366). 2015. Available online: https:/ / esa.un.org/unpd/wup/Publications/Files/WUP2014-Report. pdf (accessed on 6 September 2020).

41. Bertuzzi, N. Urban Regimes and the Right to the City: An Analysis of the No Expo Network and its Protest Frames. Rev. Critica Ciências Sociais 2017, 107-128. [CrossRef]

42. Siokas, G.; Tsakanikas, A.; Siokas, E. Implementing smart city strategies in Greece: Appetite for success. Cities 2021, 108, 102938. [CrossRef]

43. Chourabi, H.; Nam, T.; Walker, S.; Gil-Garcia, J.R.; Mellouli, S.; Nahon, K.; Pardo, T.A.; Scholl, H.J. Understanding Smart Cities: An Integrative Framework. In Proceedings of the 2012 45th Hawaii International Conference on System Sciences, Maui, HI, USA, 4-7 January 2012; Institute of Electrical and Electronics Engineers (IEEE): Piscataway Township, NJ, USA, 2012; pp. $2289-2297$.

44. Neirotti, P.; De Marco, A.; Cagliano, A.C.; Mangano, G.; Scorrano, F. Current trends in Smart City initiatives: Some stylised facts. Cities 2014, 38, 25-36. [CrossRef]

45. Kim, B.; Yoo, M.; Park, K.C.; Lee, K.R.; Kim, J.H. A value of civic voices for smart city: A big data analysis of civic queries posed by Seoul citizens. Cities 2021, 108, 102941. [CrossRef]

46. Morrow, O.; Parker, B. Care, commoning and collectivity: From grand domestic revolution to urban transformation. Urban Geogr. 2020, 41, 607-624. [CrossRef]

47. Freytag, T.; Bauder, M. Bottom-up touristification and urban transformations in Paris. Tour. Geogr. 2018, 20, 443-460. [CrossRef]

48. Roberts, P. The Evolution, Definition and Purpose of Urban Regeneration. In Hugh Sykes and Rachel Granger; Sage Publications: London, UK, 2017; pp. 9-44.

49. Cohen, B. Urbanization in developing countries: Current trends, future projections, and key challenges for sustainability. Technol. Soc. 2006, 28, 63-80. [CrossRef] 
50. The Commission on Population and Development addressed urbanization in its 51st session and took note of the report of the Secretary General on World Demographic Trends (E/CN.9/2018/5). The thematic report of the Secretary General on Sustainable Cities, Human Mobility and International Migration (E/CN.9/2018/2). Available online: https://www.un.org/en/development/ desa/population/commission/sessions/2018/index.asp (accessed on 2 October 2020).

51. Alpopi, C.; Manole, C. Integrated Urban Regeneration-Solution for Cities Revitalize. Procedia Econ. Finance 2013, 6, 178-185. [CrossRef]

52. Davies, A.; Brooks, A. Interpellation and Urban transformation: Lisbon's sardine subjects. Soc. Cult. Geogr. 2019, 1-23. [CrossRef]

53. Nofre, J.; Sánchez-Fuarros, I.; Martins, J.C.; Pereira, P.; Soares, I.; Malet-Calvo, D.; Geraldes, M.; Díaz, A.L. Exploring Nightlife and Urban Change in Bairro Alto, Lisbon. City Community 2017, 16, 330-344. [CrossRef]

54. Jackson, E.; Benson, M.; Calafate-Faria, F. Multi-sensory ethnography and vertical urban transformation: Ascending the Peckham Skyline. Soc. Cult. Geogr. 2019, 1-22. [CrossRef]

55. Balikci, E.; Koylan, D. Perceiving Urban Transformation from the Perspective of Evolutionary Economics: Renewal of Houses in Bağdat Street, Istanbul. J. Econ. Issues 2020, 54, 164-182. [CrossRef]

56. Grübler, A.; Fisk, D. Energizing Sustainable Cities: Assessing Urban Energy; Routledge: Abingdon, UK, 2013.

57. Schlappa, H.; Neill, W.J.V. From Crisis Tochoice: Re-Imagining the Future in Shrinking Cities; URBACT Secretariat: Paris, France, 2013.

58. Nagenborg, M. Urban robotics and responsible urban innovation. Ethics Inf. Technol. 2020, 22, 345-355. [CrossRef]

59. Bingham, T. The Rule of Law; Penguin: London, UK, 2011.

60. Domaradzka, A. Urban Social Movements and the Right to the City: An Introduction to the Special Issue on Urban Mobilization. Volunt. Int. J. Volunt. Nonprofit Organ. 2018, 29, 607-620. [CrossRef]

61. Bitusíková, A. Urban activism in Central and Eastern Europe: A theoretical framework. Slov. Narodop. 2015, 63, 326-338.

62. Frantzeskaki, N.; Dumitru, A.; Anguelovski, I.; Avelino, F.; Bach, M.; Best, B.; Binder, C.; Barnes, J.; Carrus, G.; Egermann, M.; et al. Elucidating the changing roles of civil society in urban sustainability transitions. Curr. Opin. Environ. Sustain. 2016, 22, 41-50. [CrossRef]

63. Burbank, M.; Andranovich, G.; Heying, C. Olympic Dreams: The Impact of Mega Events on Local Politics; Lynne Rienner: Boulder, CO, USA, 2001.

64. Sassen, S. The Global Street Comes to Wall Street, Possible Futures. Social Science Research Council. 2011. Available online: http:/ / www.possible-futures.org/2011/11/22/the-global-street-comes-to-wall-street/ (accessed on 22 February 2020).

65. Keymolen, E.; Voorwinden, A. Can we negotiate? Trust and the rule of law in the smart city paradigm. Int. Rev. Law, Comput. Technol. 2020, 34, 233-253. [CrossRef]

66. Terkenli, T.S. Landscape and justice: The case of Greeks, space and law. Landsc. Res. 2020, 1-14. [CrossRef]

67. Skaloš, J.; Kašparová, I. Landscape memory and landscape change in relation to mining. Ecol. Eng. 2012, 43, 60-69. [CrossRef]

68. Leal, C. Landscapes of Freedom; JSTOR, University of Arizona Press: Tucson, AZ, USA, 2018.

69. Adie, B.A.; De Bernardi, C. Oh my god what is happening? Historic second home communities and post-disaster nostalgia. J. Heritage Tour. 2020, 1-12. [CrossRef]

70. Davis, F. Yearning for Yesterday: A Sociology of Nostalgia; Free Press: New York, NY, USA, 1979.

71. Boym, S. The Future of Nostalgia; Basic Books: New York, NY, USA, 2001.

72. Löwenthal, D. Past Time, Present Place: Landscape and Memory. Geogr. Rev. 1975, 65. [CrossRef]

73. Meng, Z.; Cai, L.A.; Day, J.; Tang, C.-H.; Lu, Y.; Zhang, H. Authenticity and nostalgia-Subjective well-being of Chinese rural-urban migrants. J. Heritage Tour. 2019, 14, 506-524. [CrossRef]

74. Braun, V.; Clarke, V. Using thematic analysis in psychology. Qual. Res. Psychol. 2006, 3, 77-101. [CrossRef]

75. Braun, V.; Clarke, V.; Weate, P. Using thematic analysis in sport and exercise research. In Routledge Handbook of Qualitative Research in Sport and Exercise; Smith, B., Sparkes, A.C., Eds.; Routledge: London, UK, 2016; pp. 191-205.

76. Clarke, V.; Braun, V. Teaching thematic analysis: Overcoming challenges and developing strategies for effective learning. Psychologist 2013, 26, 120-123.

77. Meilutis, M. Šimašius: Pliažas Lukiškių Aikštejje Irengtas, Kad Galètume Džiaugtis Iškovota Laisve. Delfi. 2020. Available online: https: / / www.delfi.lt/news / daily / lithuania/simasius-pliazas-lukiskiu-aiksteje-irengtas-kad-galetume-dziaugtis-iskovotalaisve.d?id=84603629 (accessed on 10 September 2020).

78. Ižymybès Apie Lukiškių Aikštès Paplūdimị: Perspjovė Net Auksinio Liūto Merginas. Diena.lt. 2020. Available online: https:/ / m.diena.lt/naujienos/laisvalaikis-ir-kultura/zvaigzdes-ir-pramogos/lukiskiu-aikstes-papludimys-sukele-izymybiudiskusijas-974072 (accessed on 14 September 2020).

79. Grigaliūnaitè, V. Lukiškiu aikštę iš Vilniaus ketinama atimti ịstatymu, R.Šimašius tai vadina noru nubausti Vilnių. 15 min. 2020. Available online: https://www.15min.lt/naujiena/aktualu/lietuva/lukiskiu-aikste-is-vilniaus-ketinama-atimti-istatymuregistruotos-tai-lemsiancios-pataisos-56-1380388?comments\&copied (accessed on 2 September 2020).

80. Tracevičiūtè, S. Seime svarstant Lukiškiu aikštès likima pylèsi ne tik argumentai, bet ir užuominos apie erotines fantazijas. 15 min. 2020. Available online: https://www.15min.lt/naujiena/aktualu/lietuva/seime-svarstant-klausima-del-lukiskiu-aikstes-likimonuskambejo-pasvarstymas-apie-r-karbauskio-erotines-fantazijas-56-1381624?copied (accessed on 5 September 2020).

81. Butkus, T.S. Apie Laisvę ir Urbanistiką: Keturios Pastabos dẻl Lukiškių Pliažo. 2020. Available online: http:// pilotas.lt/2020/06/ 26/architektura/apie-laisve-ir-urbanistika-keturios-pastabos-del-lukiskiu-pliazo/ (accessed on 25 September 2020). 
82. Tiškus, G. Investigation of Representative Characteristics of Lukiškių Square in Vilnius / Lukiškiu Aikštès Vilniuje reprezentaciniu Savybiu Tyrimas. Moksl. Liet. Ateitis 2018, 10, 1-7. [CrossRef]

83. Buivydas, R.; Samalavičius, A. Public Spaces in Lithuanian Cities: Legacy of Dependence and Recent Tendencies. Urban Stud. Res. 2011, 1-9. [CrossRef]

84. Rimaitè, V. Political Relationship among Monuments: Monuments as the Subject of political Debate. Politologija 2019, 96, 60-91. [CrossRef]

85. Tiškus, G. Some Theoretical Essences of Lithuania Squares Formation Kai Kurios Teorinès Lietuvos Aikščiu Formavimo Esmès. Moksl. Liet. Ateitis 2016, 8, 92-101. [CrossRef]

86. LRT.lt. Lithuania Decides to Lift Quarantine. Available online: https://www.lrt.lt/en/news-in-english/19/1187146/lithuaniadecides-to-lift-quarantine (accessed on 12 October 2020).

87. Brazaityte, E. Beach Vibes in Vilnius: Largest City Square Turns into Pop-Up Beach 17. Vilnius.lt. 2020. Available online: https: //vilnius.lt/en/2020/06/25/beach-vibes-in-vilnius-largest-city-square-turns-into-pop-up-beach/ (accessed on 14 September 2020).

88. Linden, G. Profesorius G. Čaikauskas Apie Pliažą Lukiškiu Aikštèje: Tai-Labai Netikètas Akibrokštas, Spectrum. 2020. Available online: https:/ / structum.lt/straipsnis / profesorius-g-caikauskas-apie-pliaza-lukiskiu-aiksteje-tai-labai-netiketas-akibrokstas / (accessed on 14 September 2020).

89. LRT.lt. Vilnius Dismantles Controversial 'Open Beach' on Central Square. Available online: https://www.lrt.lt/en/news-inenglish/19/1223537/vilnius-dismantles-controversial-open-beach-on-central-square (accessed on 5 October 2020).

90. Butkus, T.S. Miestas kaip ìvykis. Miesto koncepcijos kaita ir kultūrinè miesto funkcija. Lit. ir Men. 2006, 7, 3106.

91. Rubavičius, V. Miesto tapatumas ir išskirtinumas globalizacijos salygomis. Urban. ir Archit. 2005, 24, 157-163.

92. Lukšyte, I.; Architektas, T. Grunskis: Viešosios Erdvès Keičiasi Lètai, Bet ne Žmoniu Lūkesčiai. 2020. Available online: https:/ / sa.lt/architektas-t-grunskis-viesosios-erdves-keiciasi-letai-bet-ne-zmoniu-lukesciai/ (accessed on 14 September 2020).

93. Grunskis, T. Lukiškių aikštès estetinès transformacijos problema Europos miesto aikščiu tradicijos diskurse. Urban. Archit. 2000, 24, 119-134.

94. Butkus, T.S. Potential of City's Cultural Function and Its Forms of Expression in Urban. J. Arch. Urban. 2007, 31, 87-95. [CrossRef]

95. Glover, T.D.; Bates, N.R. Recapturing a Sense of Neighbourhood Since Lost: Nostalgia and the Formation of First String, a Community Team Inc. Leis. Stud. 2006, 25, 329-351. [CrossRef]

96. Smith, L.; Campbell, G. 'Nostalgia for the future': Memory, nostalgia and the politics of class. Int. J. Heritage Stud. 2017, 23, 612-627. [CrossRef]

97. Palmberger, M. Why alternative memory and place-making practices in divided cities matter. Space Polity 2019, 23, 243-249. [CrossRef]

98. Christou, P. Tourism experiences as the remedy to nostalgia: Conceptualizing the nostalgia and tourism nexus. Curr. Issues Tour. 2020, 23, 612-625. [CrossRef]

99. Gupta, H.; Medappa, K. Nostalgia as Affective Landscape: Negotiating Displacement in the "World City". Antipode 2020, 52, 1688-1709. [CrossRef]

100. Montreal City Council. Montreal Charter of Rights and Responsibilities. 2005. Available online: https:/ ville.montreal.qc.ca/pls / portal/docs/page/charte_mtl_fr/media/documents/charte_montrealaise_english.pdf (accessed on 14 September 2020).

101. Scott, A.J.; Storper, M. The Nature of Cities: The Scope and Limits of Urban Theory. Int. J. Urban Reg. Res. 2015, 39, 1-15. [CrossRef]

102. Heatherington, C.; Jorgensen, A.; Walker, S. Understanding landscape change in a former brownfield site. Landsc. Res. 2017, 44, 19-34. [CrossRef] 